\title{
Food Security during the Pandemic and the Importance of the Bioeconomy in the New Era
}

\author{
Anca C. Farcas ${ }^{1, * \mathbb{D}}$, Charis M. Galanakis ${ }^{2,3}{ }^{\mathbb{D}}$, Carmen Socaciu ${ }^{1}$, Oana L. Pop ${ }^{1} \mathbb{1}$, Dorin Tibulca ${ }^{4}$, \\ Adriana Paucean ${ }^{4}\left(\mathbb{D}\right.$, Mirela A. Jimborean ${ }^{4}$, Melinda Fogarasi ${ }^{4}$ (D), Liana C. Salanta ${ }^{1}$, Maria Tofana ${ }^{1}$ (D) \\ and Sonia A. Socaci $1, *$ (D)
}

check for

updates

Citation: Farcas, A.C.; Galanakis, C.M.; Socaciu, C.; Pop, O.L.; Tibulca, D.; Paucean, A.; Jimborean, M.A.;

Fogarasi, M.; Salanta, L.C.; Tofana, M.; et al. Food Security during the Pandemic and the Importance of the Bioeconomy in the New Era. Sustainability 2021, 13, 150. https://dx.doi.org/10.3390/su 13010150

Received: 8 December 2020 Accepted: 23 December 2020 Published: 25 December 2020

Publisher's Note: MDPI stays neutral with regard to jurisdictional claims in published maps and institutional affiliations.

Copyright: () 2020 by the authors. Licensee MDPI, Basel, Switzerland. This article is an open access article distributed under the terms and conditions of the Creative Commons Attribution (CC BY) license (https: / / creativecommons.org/ licenses/by/4.0/).
1 Department of Food Science, University of Agricultural Sciences and Veterinary Medicine Cluj-Napoca, 400372 Cluj-Napoca, Romania; carmen.socaciu@usamvcluj.ro (C.S.); oana.pop@usamvcluj.ro (O.L.P.); liana.salanta@usamvcluj.ro (L.C.S.); maria.tofana@usamvcluj.ro (M.T.)

2 Department of Research \& Innovation, Galanakis Laboratories, GR-73131 Chania, Greece; charismgalanakis@gmail.com

3 Food Waste Recovery Group, ISEKI Food Association, 1190 Vienna, Austria

4 Department of Food Technology, University of Agricultural Sciences and Veterinary Medicine Cluj-Napoca, 400372 Cluj-Napoca, Romania; dorin.tibulca@usamvcluj.ro (D.T.); adriana.paucean@usamvcluj.ro (A.P.); mirela.jimborean@usamvcluj.ro (M.A.J.); melinda.fogarasi@usamvcluj.ro (M.F.)

* Correspondence: anca.farcas@usamvcluj.ro (A.C.F.); sonia.socaci@usamvcluj.ro (S.A.S.); Tel.: +40-740-600-924 (A.C.F.); +40-745-472-589 (S.A.S.)

\begin{abstract}
One of the biggest challenges in managing the food sector during a pandemic crisis is sustaining a robust food security system and adopting the right strategies in correlating the consumers' needs and requirements with those of food safety, the producers, the distribution chain, the economic environment, and waste management. The restrictions on people's global movement, commodities, and services and the measures taken to reduce the spread of COVID-19 have disrupted food environments around the world and forced us to collectively redesign and optimize our systems using existing resources from a more sustainable perspective. This paper offers an overview of the implications of COVID-19 for the food supply chain and discusses several potential strategies for tackling short- and long-term adverse effects resulting from the pandemic.
\end{abstract}

Keywords: COVID-19; SARS-CoV-2; pandemic crises; food security; health implications; bioeconomy

\section{Introduction}

The most recent outbreak of coronavirus disease (identified from a wholesale seafood and wildlife market from the Wuhan region of China) resulted in a highly transmittable viral infection with pandemic dimensions. Although the zoonotic source of SARS-CoV-2 is not yet fully elucidated, genomic analysis suggests bats as the vital reservoir from which the worldwide spread started [1].

The new coronavirus pandemic has exposed many vulnerabilities across various domains, far beyond the medical system and its related clinical aspects. Besides the urgency of designing a medical treatment and developing an effective vaccine, issues related to patient testing, the safety of and facilities for professional healthcare providers, social and economic safety, food safety, and even mental/psychological health and domestic safety require increased attention and the implementation of a range of crisis and postcrisis management tools [2,3].

The strict lockdowns, social distancing, the halting of all nonessential economic activities, and all of the protectionist restrictions imposed by authorities to control the coronavirus outbreaks have caused disruptions in most production and supply chains around the world [4]. These disruptions are, specifically, the restrictions on people's global movement, delays in the supply of raw materials and import-export transactions, price fluctuations, the lack of workers in agriculture, increased farming costs, and distribution 
deficiencies. Other similar consequences have forced many companies to relocate, restructure, find alternative sources, and rapidly redesign their production processes, or in some cases, temporarily or permanently suspend their activities. Hence, in many developing countries and beyond, COVID-19 has had a severe impact on employment and income, generating a significant food crisis and insecurity for a growing number of people unable to afford their basic daily food $[5,6]$. What the pandemic has highlighted is the necessity of using resources by adopting the principles of sustainability to mitigate the devastating effects of the crises [7].

This paper offers an overview of the implications of COVID-19 for the food supply chain, highlighting global food security issues and the behavior of consumers under the pressures of a lockdown. It also emphasizes the importance of managing resources by applying sustainable principles and explains several potential strategies that could be useful for minimizing short- and long-term pandemic drawbacks (e.g., the bioeconomy and food bank concepts).

\section{A Brief Overview of SARS-CoV-2 Health Implications}

In December 2019, the Wuhan region of China faced an alarming number of cases of pneumonia of unknown etiology. Shortly afterward, it was assumed that a small local fish and wild animal market was the starting point of the unknown viral infection [8]. Following multiple investigations, a genome sequencing of respiratory tract samples from the pneumonia patients led to the isolation of a new, novel coronavirus and placed it in the Betacoronavirus genus (betaCoV), which also includes SARS-CoV and MERS-CoV [9].

Further epidemiological and genomic analysis revealed that 2019-nCoV shares $89 \%$ nucleotide identity with bat SARS-like CoVZXC21 and 82\% identity with human SARSCoV. Therefore, the International Committee on Taxonomy of Viruses and the World Health Organization (WHO) decided to name it SARS-CoV-2 [10,11], while the disease caused is called COVID-19.

Despite rigorous global containment and quarantine restrictions, the incidence of COVID-19 continues to rise, with 66,422,058 laboratory-confirmed cases and 1,532,418 deaths reported worldwide to date (7 December 2020). Moreover, 9 months after the WHO declared the new coronavirus a pandemic, the contamination rate is still alarming, with almost 550,000 new positive tests reported daily globally [12].

Usually, the most common symptoms of COVID-19 are a fever, a dry cough and sore throat, fatigue, diarrhea, breath shortness, and headaches. However, a large proportion of COVID-19 patients are exposed to a severe form of the disease with various complications, which can cause acute respiratory distress syndrome; hypoxia, dyspnea, and neurological deficiencies; acute heart injury, acute kidney, liver, and gastrointestinal problems; secondary infection with bacteria; and even death [13-16]. The maximum incubation period is assumed to be up to 14 days, while the average period between the onset of symptoms and death can range from 2 to 8 weeks [17]. However, the incidence and incubation period for mild or severe cases may differ, being closely related to the age of the patient; their immune response; or other pre-existing comorbidities including diabetes, cardiovascular disease, cerebrovascular disease, endocrine disease, chronic lung or kidney disease, and respiratory deficiencies $[9,18]$.

Indeed, the pandemic severity of COVID-19 demands rigorous surveillance and ongoing monitoring to accurately track its evolution, transmissibility, and pathogenicity [19]. Clinical care for a confirmed COVID-19 case prioritizes early recognition, immediate isolation, and the implementation of appropriate measures to prevent the spread of the infection, followed by the provision of symptomatic care for those with a mild illness and optimized supportive care for those with severe symptoms. WHO is also monitoring the accelerated global vaccine development effort; of the 52 vaccine candidates in clinical evaluation, 13 were in phase 3 of clinical trials by the end of November 2020 [20].

To date, the most widely used identification technique is real-time reverse transcription polymerase chain reaction (RT-PCR) on a nasopharyngeal swab or sputum samples. 
Serological tests can only be applied to identify antibodies generated by the body's defense system, not the virus's genetic material. It can take anywhere between several days to several weeks to develop enough antibodies to be detected in a blood test; therefore, the molecular method remains the safest method to diagnose an active coronavirus infection [21].

\section{Food Security and Insecurity}

As a result of the emergence of the coronavirus outbreak, the crisis has exacerbated all existing discrepancies in the food sector, leading to a significant destabilization of the global food security system. The food systems comprise a complex of closely correlated stages meant both to ensure the "farm to fork traceability" and security of the final products in all processing, distribution, consumption, and waste management activities and to maintain a connection between all involved parts [22]. Thus, one of the biggest challenges in managing the food sector during a pandemic crisis is to adopt an effective strategy in correlating the needs of consumers, food safety, producers, the distribution chain, the economic environment, and waste management. Even if the amount of food produced today would theoretically be enough to sustain all of humanity, the socioeconomic differences and the unequal distribution of resources (in different regions around the world) would generate discrepancies in living standards. Consequently, in developed countries, food abundance inevitably leads to a large amount of food waste, while in underdeveloped countries, more than one billion people have difficulty in purchasing their essential daily commodities [23].

The COVID-19 pandemic has had a significant impact on the food industry not only in developing countries, where the repercussions are already being felt, but also in developed countries with relatively stable food sectors, where the repercussions will be felt in the long term. From an economic point of view, pandemic effects have been intensified by the loss of more than 200 million jobs. Consequently, according to the prediction of the United Nations World Food Programme (WFP), the number of people across the planet facing acute food insecurity stands to rise to 265 million in 2020, almost doubling from the 135 million reported in 2019 [24].

According to the official Food and Agriculture Organization (FAO) definition, "Food security is a situation that exists when all people, at all times, have physical, social and economic access to sufficient, safe and nutritious food that meets their dietary needs and food preferences for an active and healthy life." When people do not have adequate physical, social, or economic access to food as defined above, the phenomenon of food insecurity will inevitably occur [25]. Before the coronavirus outbreak, food insecurity was already a severe problem, mainly due to the increased number of people with limited access to food. Under the current pandemic, food security has declined significantly [26].

At the community level, food access and availability have been significantly affected, primarily due to disruption in the transportation, distribution, and delivery chain. At the individual level, nutritional status, also considered an indicator of food security, has been perturbed by variations in consumption behavior [27]. Moreover, due to the restrictions on people's movement imposed by the pandemic, reductions in regulatory control measures and oversight of inspection agencies in the food sector have occurred. As a consequence, food authenticity vulnerabilities have been exposed by creating suitable premises for food fraudsters to operate, thus increasing the risk of food fraud (e.g., substitution, misrepresentation, document fraud, waste diversion, illegal processing) [28].

As shown schematically in Figure 1, the consequences of pandemic disruptions have been severe and have exposed the principal vulnerabilities of the security system.

Looking to the future, increasing investment in agriculture and biotechnology research would undoubtedly have a significant impact on enhancing and maintaining more stable food security in the event of future pandemics. Advanced technologies and innovative approaches need to be adopted globally in each region to optimize regional food production capability in order to provide not only a safer but also a more sustainable source of food [5]. For example, management systems such as Vulnerability Assessment and Critical Control 
Points (VACCP) plans have already been implemented in several large food chains. Still, in the actual pandemic context, their inclusion in every supplier's food safety assurance program is likely to be accelerated [28].
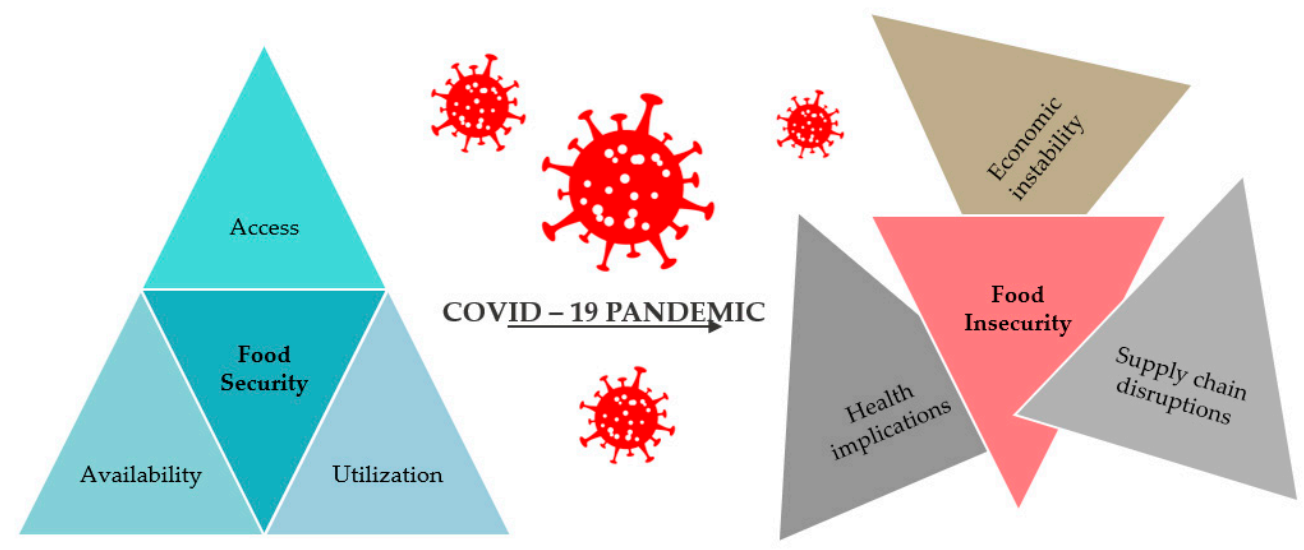

Figure 1. The repercussions of a pandemic on the stability of food security.

\section{The Importance of Nutritional Behavior during a Pandemic}

Nowadays, different forms of malnutrition affect one in three people globally. This is concerning because nutritional imbalances and a deficient immune system are, in many cases, starting points for the generation or aggravation of other diseases.

Both underdeveloped and high-income countries face problems caused by inadequate nutrition. These issues are reflected by undernutrition, anorexia, and micronutrient deficiencies, as well as an overweight population, obesity, and diet-related noncommunicable diseases [29]. Consequently, nutritional deficiencies of high-quality macro- and micronutrients are strongly associated with a depressed immune function and increased susceptibility to infection $[27,30]$. Under the pressure of the pandemic, people have had to rethink how they procure and select food resources and should have been more aware of the importance of maintaining a healthy organism. Despite that, panic buying affected diet quality, as people may have encountered various impediments in purchasing healthy fresh food [7]. There is clear evidence that the increase in prices for fresh vegetables, fruits, and rich protein foods (such as meat and fish) has led to a shift towards ready-to-eat snacks, frozen or processed meat, and canned and other nonperishable foods. From a nutritional point of view, this can be translated into a higher caloric intake but a lower nutritional quality $[27,31]$. Associated with prolonged sedentary time, all of these imbalances can increase the risk of developing obesity and nutrient imbalance in the long term, as well as other related complications like diabetes, dyslipidemia, and cardiovascular diseases [32,33]. Recent evidence suggests that patients with different malnourishment deficiencies or who have specific comorbidities have a high risk of requiring hospitalization in intensive care units or conditions of mechanical ventilation, presenting a higher rate of mortality from SARS-CoV-2 syndrome [34].

Figure 2 explains the potential interdependence between the economic and food crisis generated by the measures applied against the spread of the virus and the fact that nutritional deficiencies caused by limited access to a balanced diet make the human organism more exposed to the risk of infection. People suffering from malnutrition are at a greater risk of developing severe COVID-19 symptoms as a result of associated health conditions and noncommunicable diseases, which compromise the immune system. As a consequence, a weakened immune system reduces the chances of recovery and significantly increases the period of convalescence; therefore, food safety can be considered a vital pawn in the fight against the new coronavirus from this point of view. 


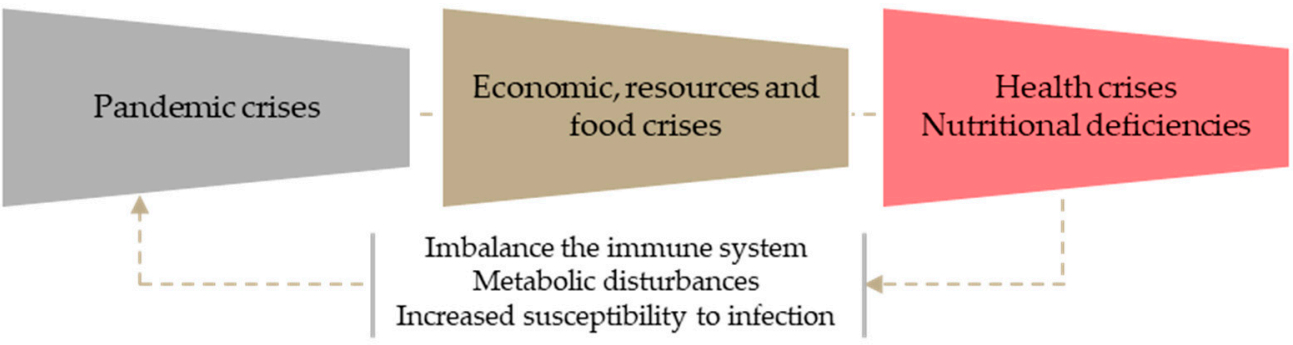

Figure 2. The potential connection between the availability of resources, health status, nutrition, and susceptibility to infection.

The response of human cellular immunity mechanisms to the SARS-CoV-2 viral infection is strongly influenced by host nutrition, mainly by the presence or absence of specific micronutrients and bioactive molecules [14,35-38]. An indirect approach is to use different mechanisms that sustain the absorption and bioavailability of bioactive molecules. In this sense, the most efficient and widely used means are fermentation (fermented foods, pro- and prebiotics) [39], enzymatic treatments (use of enzyme supplements and foods rich in enzymes) [40], or micro- and nanoencapsulation (targeted and controlled release and protection) [41].

In the COVID-19 fight, the viral host resistance of the human body consists of support from both macro- and micronutrients (but especially from micronutrients), namely vitamins A, C, D, E, B6, B9, and B12; copper (Cu); magnesium (Mg); selenium (Se); iron (Fe); and zinc (Zn) [42-46]. The wall that forms the first defensive barrier against the virus is the respiratory tract, with its physical and biochemical functions sustained by the presence of vitamin $\mathrm{A}$ and $\mathrm{Fe}[47,48]$. The mechanisms of the micronutrient action are complicated. Concerning the vitamins and minerals that directly influence the respiratory functions, vitamins A, $\mathrm{C}$, and D and the mineral $\mathrm{Zn}$ can modulate membrane functionality (integrity, fluidity, communication, and capacity to repair) [48-50]. Dietary selenium supplementation can increase the antiviral immune responses by, for example, cutting down the pathogenicity of virus infection in the avian case [51]. Similarly, selenium supplement intake seems to yield good results in COVID-19-susceptible hosts [15]. Thus, suitable and equilibrate nutrition, with properly regulated health monitoring, can significantly improve the immune response to SARS-CoV-2 viral infection.

In addition to the medical health and general safety of the population, psychological wellbeing and mental safety are subjects that cannot be overlooked [2]. Various psychological problems and related consequences, including panic, stress, anxiety, depression, and uncertainty have emerged progressively during the COVID-19 outbreak [52]. Besides the fear of contamination and socioeconomic imbalances, anxiety and uncertainty have also tended to be exacerbated by an inadequate supply of necessary resources (e.g., food, water, clothing, etc.) and restricted access to some commodities during the quarantine period [53].

\section{Bioeconomy Concept Importance in Pandemic}

The instability of our global supply chains began to be felt from the early stages of the pandemic, starting with the acute crisis of medical equipment and immediately extending to other indispensable areas such as the food industry. Under the global experience of these pandemic emergencies, there has never been a more proper moment to prioritize and accelerate the implementation of the principles of a circular economy vision.

Food loss and agroindustrial byproducts represent a continuously growing global issue, posing a challenge to food safety and security and negatively impacting the economy and environmental stability. According to FAO, approximately one-third of the world's food is inefficiently managed and wasted every year [4]. In the current crisis, the dominant system of the linear economy model, based on the "take-make-consume-dispose" approach, has proved to be inefficient in supporting the sustainable management of resources. Contrary to the principles of the linear economy, the bioeconomy model considers waste as 
a new resource with high potential to be converted into various biomaterials, biofuels, and other added-value products [54].

While in low-income countries waste occurs mainly during the processing steps of raw materials, in middle- and high-income countries, waste is generated in the highest proportion in the distribution and consumption stages. Nevertheless, the impact of the pandemic has significantly changed consumer behavior and attitudes towards purchasing and consumption activities, and consumers are also showing increased attention to reducing food waste [4]. Although the population tended to invest in substantial reserves of nonperishable food at the beginning of the quarantine, their purchasing power has since decreased significantly. Therefore, food producers and retailers may face stock imbalances and losses caused by the degradation of perishable products.

If the residues and byproducts of the food industry were considered to be worthless until recently, now the attitude has begun to change, with new research directions being oriented towards their exploitation. Implementing the reintegration concept facilitates the conversion of agroindustrial waste into high-value products with relevant potential applications for human consumption and other necessities of daily living [55]. In this context, the biggest challenge of the scientific world is to develop efficient valorization strategies with a high degree of industrial feasibility [56]. In prioritizing resource efficiency, the closed-loop value chains that convert waste and byproducts into resources can lead to the achievement of a sustainable food system in all its three dimensions: economic, social, and environmental protection [23,57]. In this context, the management of food byproducts is encouraged to move from a linear model to a much more complex circular chain. As illustrated in Figure 3, reintegrated into a circular economy system, residues and agrifood byproducts can generate a series of products with applicability in the food, cosmetics, pharmaceutical, agriculture, or fuel industries.

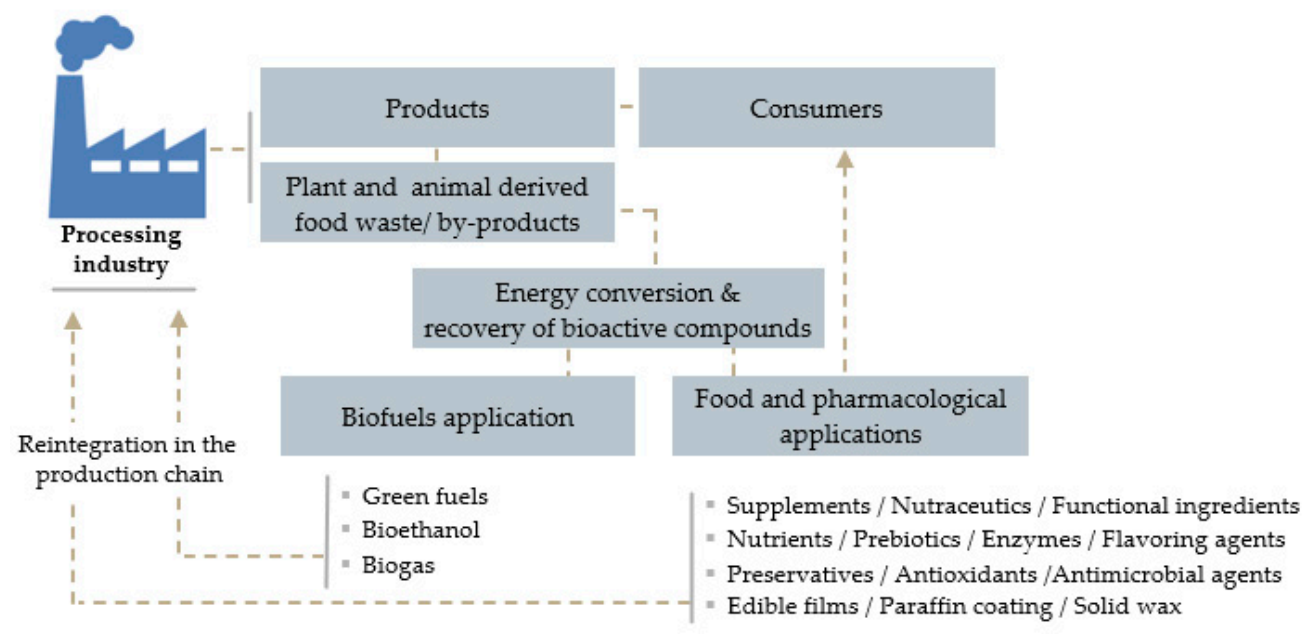

Figure 3. Bioeconomy and agroindustrial waste conceptual diagram.

The most complicated decision in reintegrating waste into a biorefinery model is to establish the usefulness and new destination of the novel products. In this sense, the greatest challenge for researchers is to develop and optimize extraction and conversion protocols with a degree of feasibility to ensure their sustainability when implemented at the industrial level [58,59].

The bioeconomy approach could have a significant impact not only on sustaining the resource demands of a post-COVID world but also on the long-term challenges of climate change, population growth, environmental degradation, and food security [5]. The implementation of the concept can also be seen as a perspective to promote a business model that could generate new employment opportunities [60]. 


\section{Food Banks Concept}

Considering the concept of the bioeconomy, the principles of which focus on reuse, redesign, waste minimization, and recycling, the opportunity to leverage the benefits of the immediate community instead of global supply chains seems to be a sustainable approach that deserves to be investigated [61]. A well-developed and stable local distribution chain, once integrated with the principles of the bioeconomy, could temporarily support the problems of the community in different crises through charitable actions. As a result, various volunteer-based associations have begun to emerge, collecting surplus resources and redistributing them where needed [62].

Food banks are a typical community-based response to household food insecurity [63]. The concept of the food bank began to materialize in 1960 in the United States. Its purpose, namely to redirect surplus products to social categories with vulnerabilities in procuring the basic food for their needs, was established from the beginning [64]. Over time, this concept was extended, addressing all segments of the food-insecure population. In Europe, the idea was first initiated in 1984 in France, and in 1986 the European Federation of Food Banks (FEBA) began the process of implementing the concept and developing a network of food banks across the continent. However, in many countries, the concept was expanded significantly only in 2010, when the repercussions of the global economic crisis affected a large part of the population. For example, the Food Waste Romania Organization reported that approximately one-third of all food products are wasted annually. This amount corresponds to about 2.55 million tons of food, while 5 million Romanians live at the poverty line and $66 \%$ of rural families cannot afford basic daily food. Thus, in 2016, Romania became a member of FEBA and began the development of a network of food banks that currently operates in five of its main cities [65].

Through food banks, edible and nonfood food products are collected from economic agents that for various reasons have lost their economic market value and are redirected to various nongovernmental organizations that provide support to disadvantaged people. This process is supported through the involvement and support of volunteers, economic agents and retailers, supermarkets, food manufacturers and processors, and any other companies and individuals who are willing to support the disadvantaged social class and reduce food waste [66,67].

Figure 4 shows a simplified diagram of the food bank concept and the main entities involved in the process.

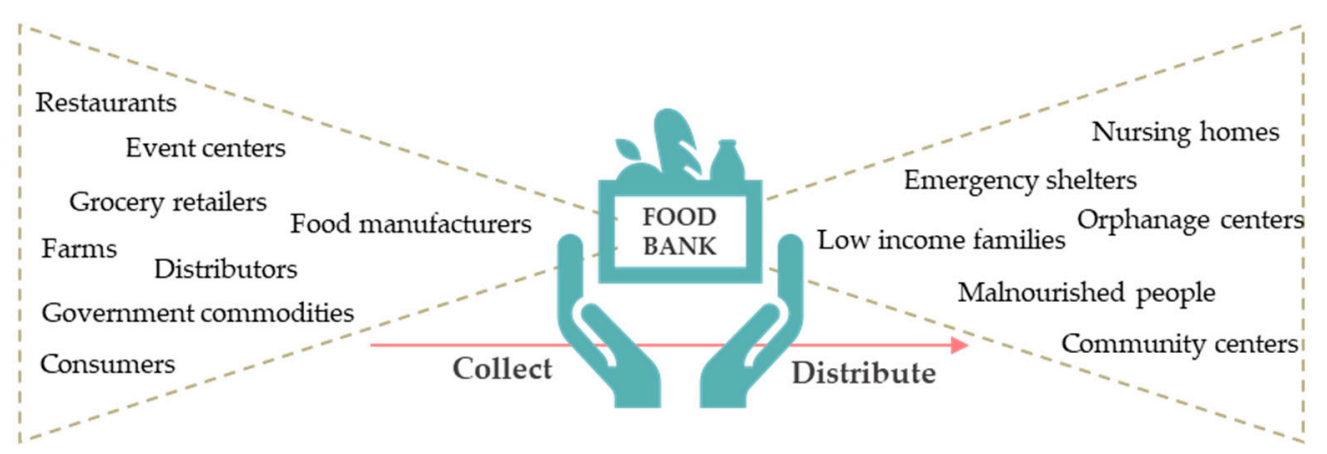

Figure 4. Food bank conceptual diagram.

In the context of a pandemic crisis, the segment of the population that needs the facilities of a food bank is gradually expanding, with the emergence of financial problems generated mainly by the temporary suspension or loss of many jobs. Without the bank collection point, the redirection of surplus food to its beneficiaries is not safe in terms of traceability and food safety. Therefore, the distribution of products is not conducted directly from supermarkets to individuals, but only through eligible partner organizations [68]. Thus, the food bank is not just a simple collection point, as its responsibilities are much more complex and its rules of operation are based on the principles of transparency and food 
safety. Throughout this process, principles such as social equity, product nutritional quality, safe and hygienic storage and transport, and environmental protection are mandatory to consider.

In Europe, over the last 9 months, the COVID-19 crisis has caused not only chaos in the medical system but also a new food emergency. According to a report of a survey conducted amongst European Food Banks, the demand for food has increased by up to 50\% compared to the precoronavirus period, and lockdown consequences continue to increase the number of people experiencing difficulties. Although collection and distribution activities are hampered by the limitations caused by the pandemic such as a reduction in the number of volunteers and donors involved, transportation difficulties, or economic difficulties, food banks have managed to adapt to the new conditions and continue to support the affected social categories [69].

\section{Conclusions and Future Trends}

The COVID-19 pandemic has exposed the weaknesses and amplified the instability in medical, social, and economic systems. Confronting the effects and chaos generated by the pandemic crisis has forced us to not only urgently identify an effective treatment scheme and a vaccine to immunize the population, but also streamline and implement a series of sustainable strategies to rebalance all affected sectors. In this sense, in addition to the medical and research fields, the food sector must be considered an essential pillar of survival that must be prioritized for the implementation of effective support strategies. As the COVID-19 pandemic persists, considerable attention has been focused on the stability of food supply chains and their impact on global food security. Understanding of the various safety implications of the current pandemic has raised awareness among consumers, scientists, and authorities that similar (or even more severe) crises may occur and that proper management is crucial for minimizing their negative effects.

Author Contributions: Conceptualization, A.C.F. and S.A.S.; investigation, M.A.J., A.P., L.C.S., M.T., M.F. and D.T.; writing — original draft preparation, A.C.F.; writing — review and editing, S.A.S. and C.M.G.; project administration, C.S. and O.L.P. All authors have read and agreed to the published version of the manuscript.

Funding: This research received no external funding.

Acknowledgments: This work was supported by three grants from the Ministry of Research and Innovation, CNCS, UEFISCDI, project number: PN-III-P1-1.1-PD-2016-0869, PN-III-P1-1.1-TE-20160973, and PN-III-P1-1.1-PD-2019-0475, within PNCDI III.

Conflicts of Interest: The authors declare no conflict of interest.

\section{References}

1. Letko, M.; Seifert, S.N.; Olival, K.J.; Plowright, R.K.; Munster, V.J. Bat-borne virus diversity, spillover and emergence. Nat. Rev. Microbiol. 2020, 18, 461-471. [CrossRef]

2. Haghani, M.; Bliemer, M.C.; Goerlandt, F.; Li, J. The scientific literature on Coronaviruses, COVID-19 and its associated safetyrelated research dimensions: A scientometric analysis and scoping review. Saf. Sci. 2020, 129, 104806. [CrossRef]

3. Rizou, M.; Galanakis, I.M.; Aldawoud, T.M.; Galanakis, C.M. Safety of foods, food supply chain and environment within the COVID-19 pandemic. Trends Food Sci. Technol. 2020, 102, 223-229. [CrossRef] [PubMed]

4. Jribi, S.; Ismail, H.B.; Doggui, D.; Debbabi, H. COVID-19 virus outbreak lockdown: What impacts on household food wastage? Environ. Dev. Sustain. 2020, 22, 3939-3955. [CrossRef] [PubMed]

5. Henry, R. Innovations in agriculture and food supply in response to the COVID-19 pandemic. Mol. Plant 2020, 13, 1095-1097. [CrossRef] [PubMed]

6. Hobbs, J.E. Food supply chains during the COVID-19 pandemic. Can. J. Agric. Econ. 2020, 68, 171-176. [CrossRef]

7. Torero, M. Without food, there can be no exit from the pandemic. Nature 2020, 580, 588-589. [CrossRef]

8. Chen, W.H.; Strych, U.; Hotez, P.J.; Bottazzi, M.E. The SARS-CoV-2 vaccine pipeline: An overview. Curr. Trop. Med. Rep. 2020, 7, 61-64. [CrossRef]

9. Kaul, D. An overview of coronaviruses including the SARS-2 coronavirus-Molecular biology, epidemiology and clinical implications. Curr. Med. Res. Pract. 2020, 10, 54-64. [CrossRef] 
10. Chan, J.F.W.; Kok, K.H.; Zhu, Z.; Chu, H.; To, K.K.W.; Yuan, S.; Yuen, K.Y. Genomic characterization of the 2019 novel humanpathogenic coronavirus isolated from a patient with atypical pneumonia after visiting Wuhan. Emerg. Microbes Infect. 2020, 9, 221-236. [CrossRef]

11. Coronaviridae Study Group of the International Committee on Taxonomy of Viruses. The species severe acute respiratory syndrome related coronavirus: Classifying 2019-nCoV and naming it SARS-CoV-2. Nat. Microbiol. 2020, 5, 536-544. [CrossRef] [PubMed]

12. WHO Coronavirus Disease (COVID-19) Dashboard. Available online: https:/ / covid19.who.int/ (accessed on 8 December 2020).

13. Acter, T.; Uddin, N.; Das, J.; Akhter, A.; Choudhury, T.R.; Kim, S. Evolution of severe acute respiratory syndrome coronavirus 2 (SARS-CoV-2) as coronavirus disease 2019 (COVID-19) pandemic: A global health emergency. Sci. Total Environ. 2020, 730, 138996. [CrossRef] [PubMed]

14. Ali, I.; Alharbi, O.M. COVID-19: Disease, management, treatment, and social impact. Sci. Total Environ. 2020, $728,138861$. [CrossRef] [PubMed]

15. Zhang, J.; Taylor, E.W.; Bennett, K.; Saad, R.; Rayman, M.P. Association between regional selenium status and reported outcome of COVID-19 cases in China. Am. J. Clin. Nutr. 2020, 111, 1297-1299. [CrossRef]

16. Shereen, M.A.; Khan, S.; Kazmi, A.; Bashir, N.; Siddique, R. COVID-19 infection: Origin, transmission, and characteristics of human coronaviruses. J. Adv. Res. 2020, 24, 91-98. [CrossRef]

17. Baud, D.; Qi, X.; Nielsen-Saines, K.; Musso, D.; Pomar, L.; Favre, G. Real estimates of mortality following COVID-19 infection. Lancet Infect. Dis. 2020, 20, 773. [CrossRef]

18. Abd El-Aziz, T.M.; Stockand, J.D. Recent progress and challenges in drug development against COVID-19 coronavirus (SARSCoV-2)-An update on the status. Infect. Genet. Evol. 2020, 83, 104327. [CrossRef]

19. Sohrabi, C.; Alsafi, Z.; O’Neill, N.; Khan, M.; Kerwan, A.; Al-Jabir, A.; Iosifidis, C.; Agha, R. World Health Organization declares global emergency: A review of the 2019 novel coronavirus (COVID-19). Int. J. Surg. 2020, 76, 71-76. [CrossRef]

20. World Health Organisation (WHO). Draft Landscape of COVID-19 Candidate Vaccines. Available online: https://www.who.int/ publications / m/item/draft-landscape-of-covid-19-candidate-vaccines (accessed on 9 December 2020).

21. Huang, C.; Wang, Y.; Li, X.; Ren, L.; Zhao, J.; Hu, Y.; Zhang, L.; Fan, G.; Xu, J.; Gu, X.; et al. Clinical features of patients infected with 2019 novel coronavirus in Wuhan, China. Lancet 2020, 395, 497-506. [CrossRef]

22. Galanakis, C.M. The food systems in the era of the coronavirus (COVID-19) pandemic crisis. Foods 2020, 9, 523. [CrossRef]

23. Segneanu, A.; Grozescu, I.; Cepan, C.; Cziple, F.; Lazar, V. Food security into a circular economy. J. Food Sci. Nut. 2018, 4, 1-3. [CrossRef]

24. United Nations World Food Programme. COVID-19 Will Double Number of People Facing Food Crises Unless Swift Action Is Taken. Available online: https:/ / www.wfp.org/news/covid-19-will-double-number-people-facing-food-crises-unless-swiftaction-taken (accessed on 20 August 2020).

25. Food and Agriculture Organization of the United Nations (FAO Rome). Trade Reforms and Food Security: Conceptualizing the Linkages. 2003. Available online: http:/ / www.fao.org/3/a-y4671e.pdf (accessed on 14 August 2020).

26. Udmale, P.; Pal, I.; Szabo, S.; Pramanik, M.; Large, A. Global food security in the context of COVID-19: A scenario-based exploratory analysis. Prog. Disaster Sci. 2020, 7, 100120. [CrossRef]

27. Naja, F.; Hamadeh, R. Nutrition amid the COVID-19 pandemic: A multi-level framework for action. J. Clin. Nutr. 2020, 74, 1117-1121. [CrossRef]

28. Crew, S. Food Safety Risk during the Pandemic. JFST 2020, 34, 14-17. Available online: https:/ /ifst.onlinelibrary.wiley.com/doi/ 10.1002/fsat.3402_4.x (accessed on 9 December 2020).

29. Turner, C.; Aggarwal, A.; Walls, H.; Herforth, A.; Drewnowski, A.; Coates, J.; Kalamatianou, S.; Kadiyala, S. Concepts and critical perspectives for food environment research: A global framework with implications for action in low-and middle-income countries. Glob. Food Sec. 2018, 18, 93-101. [CrossRef]

30. Rusu, I.G.; Suharoschi, R.; Vodnar, D.C.; Pop, C.R.; Socaci, S.A.; Vulturar, R.; Istrati, M.; Moroșan, I.; Farcas, A.C.; Kerezsi, A.D.; et al. Iron supplementation influence on the gut microbiota and probiotic intake effect in iron deficiency-A literature-based review. Nutrients 2020, 12, 1993. [CrossRef]

31. Batlle-Bayer, L.; Aldaco, R.; Bala, A.; Puig, R.; Laso, J.; Margallo, M.; Vázquez-Rowe, I.; Maria Antó, J.; Fullana-i-Palmera, P. Environmental and nutritional impacts of dietary changes in Spain during the COVID-19 lockdown. Sci. Total Environ. 2020, 748, 141410. [CrossRef]

32. Bracale, R.; Vaccaro, C.M. Changes in food choice following restrictive measures due to Covid-19. Nutr. Metab. Cardiovasc. Dis. 2020, 30, 1423-1426. [CrossRef]

33. Mattioli, A.V.; Sciomer, S.; Cocchi, C.; Maffei, S.; Gallina, S. Quarantine during COVID-19 outbreak: Changes in diet and physical activity increase the risk of cardiovascular disease. Nutr. Metab. Cardiovasc. Dis. 2020, 30, 1409-1417. [CrossRef]

34. Handu, D.; Moloney, L.; Rozga, M.; Cheng, F.W. Malnutrition care during the COVID-19 pandemic: Considerations for registered dietitian nutritionists. J. Acad. Nutr. Diet. 2020. [CrossRef]

35. Im, J.H.; Je, Y.S.; Baek, J.; Chung, M.-H.; Kwon, H.Y.; Lee, J.-S. Nutritional status of patients with coronavirus disease 2019 (COVID-19). Int. J. Infect. Dis. 2020, 100, 390-393. [CrossRef] [PubMed]

36. Khan, I.; Haleem, A.; Javaid, M. Analysing COVID-19 pandemic through cases, deaths, and recoveries. J. Oral Biol. Craniofac. Res. 2020, 10, 450-469. [CrossRef] 
37. Quiles, J.L.; Rivas-García, L.; Varela-López, A.; Llopis, J.; Battino, M.; Sánchez-González, C. Do nutrients and other bioactive molecules from foods have anything to say in the treatment against COVID-19? Environ. Res. 2020, 191, 110053. [CrossRef] [PubMed]

38. Taghizadeh-Hesary, F; Akbari, H. The powerful immune system against powerful COVID-19: A hypothesis. Med. Hypotheses 2020, 140, 109762. [CrossRef] [PubMed]

39. Pop, O.L.; Salanță, L.C.; Pop, C.R.; Coldea, T.; Socaci, S.A.; Suharoschi, R.; Vodnar, D.C. Prebiotics and Dairy Applications. In Dietary Fiber: Properties, Recovery, and Applications; Galanakis, C.M., Ed.; Academic Press: London, UK, 2019 ; pp. $247-277$. [CrossRef]

40. Sandberg, A.S. Bioavailability of minerals in legumes. Br. J. Nutr. 2002, 88, 281-285. [CrossRef] [PubMed]

41. Diaconeasa, Z.; Barbu-Tudoran, L.; Coman, C.; Leopold, L.; Mesaros, A.; Pop, O.; Rugină, D.; Ştefan, R.; Tăbăran, F.; Tripon, S.; et al. Cerium oxide nanoparticles and its cytotoxicity human lung cancer cells. Rom. Bio. Lett. 2015, 20, 10679-10687.

42. Ali, N. Role of vitamin D in preventing of COVID-19 infection, progression and severity. J. Infect. Public Health 2020, 13, 1373-1380. [CrossRef]

43. De Almeida Brasiel, P.G. The key role of zinc in elderly immunity: A possible approach in the COVID-19 crisis. Clin. Nutr. ESPEN 2020, 38, 65-66. [CrossRef]

44. Gasmi, A.; Noor, S.; Tippairote, T.; Dadar, M.; Menzel, A.; Bjørklund, G. Individual risk management strategy and potential therapeutic options for the COVID-19 pandemic. J. Allergy Clin. Immunol. 2020, 215, 108409. [CrossRef]

45. Kieliszek, M.; Lipinski, B. Selenium supplementation in the prevention of coronavirus infections (COVID-19). Med. Hypotheses 2020, 143, 109878. [CrossRef]

46. Shakoor, H.; Feehan, J.; Al Dhaheri, A.S.; Ali, H.I.; Platat, C.; Ismail, L.C.; Apostolopoulos, V.; Stojanovska, L. Immune-boosting role of vitamins D, C, E, zinc, selenium and omega-3 fatty acids: Could they help against COVID-19? Maturitas 2021, 143, 1-9. [CrossRef] [PubMed]

47. Haryanto, B.; Suksmasari, T.; Wintergerst, E.; Maggini, S. Multivitamin supplementation supports immune function and ameliorates conditions triggered by reduced air quality. Vitam. Miner. 2015, 3, 1000128. [CrossRef]

48. Maggini, S.; Pierre, A.; Calder, P.C. Immune function and micronutrient requirements change over the life course. Nutrients 2018, 10, 1531. [CrossRef] [PubMed]

49. Chew, B.P.; Park, J.S. Carotenoid action on the immune response. J. Nutr. 2004, 134, 257-261. [CrossRef]

50. Clark, A.; Mach, N. Role of vitamin D in the hygiene hypothesis: The interplay between vitamin D, vitamin D receptors, gut microbiota, and immune response. Front. Immunol. 2016, 7, 627. [CrossRef]

51. Shojadoost, B.; Kulkarni, R.R.; Yitbarek, A.; Laursen, A.; Taha-Abdelaziz, K.; Alkie, T.N.; Barjesteh, N.; Quinteiro-Filho, W.M.; Smith, T.K.; Sharif, S. Dietary selenium supplementation enhances antiviral immunity in chickens challenged with low pathogenic avian influenza virus subtype H9N2. Vet. Immunol. Immunopathol. 2019, 207, 62-68. [CrossRef]

52. Duan, L.; Zhu, G. Psychological interventions for people affected by the COVID-19 epidemic. Lancet Psychiatry 2020, 7, 300-302. [CrossRef]

53. Serafini, G.; Parmigiani, B.; Amerio, A.; Aguglia, A.; Sher, L.; Amore, M. The psychological impact of COVID-19 on the mental health in the general population. QJM Int. J. Med. 2020, 113, 531-537. [CrossRef]

54. Teigiserova, D.A.; Hamelin, L.; Thomsen, M. Towards transparent valorization of food surplus, waste and loss: Clarifying definitions, food waste hierarchy, and role in the circular economy. Sci. Total Environ. 2020, 706, 136033. [CrossRef]

55. Campos, D.A.; Gómez-García, R.; Vilas-Boas, A.A.; Madureira, A.R.; Pintado, M.M. Management of fruit industrial by-productsA case study on circular economy approach. Molecules 2020, 25, 320. [CrossRef]

56. Farcas, A.C.; Socaci, S.A.; Diaconeasa, Z.M. Introductory Chapter: From Waste to New Resources. In Food Preservation and Waste Exploitation; Socaci, S.A., Farcas, A.C., Aussenac, T., Eds.; IntechOpen: London, UK, 2019; pp. 1-11. [CrossRef]

57. Sherwood, J. The significance of biomass in a circular economy. Bioresour. Technol. 2020, 300, 122755. [CrossRef] [PubMed]

58. Mak, T.M.; Xiong, X.; Tsang, D.C.; Iris, K.; Poon, C.S. Sustainable food waste management towards circular bioeconomy: Policy review, limitations and opportunities. Bioresour. Technol. 2020, 297, 122497. [CrossRef] [PubMed]

59. Socaci, S.A.; Farcas, A.C.; Vodnar, D.C.; Tofana, M. Food Wastes as Valuable Sources of Bioactive Molecules. In Superfood and Functional Food-The Development of Superfoods and Their Roles as Medicine; Shiomi, N., Ed.; Intech Open: London, UK, 2017; pp. 75-93. [CrossRef]

60. Stavropoulos, S.; Burger, M.J.; Dufourmont, J. Urban circular policies and employment through greenfield FDI. Sustainability 2020, 12, 1458. [CrossRef]

61. Korhonen, J.; Honkasalo, A.; Seppala, J. Circular economy: The concept and its limitations. Ecol. Econ. 2018, 143, 37-46. [CrossRef]

62. Wetherill, M.S.; White, K.C.; Seligman, H. Charitable food as prevention: Food bank leadership perspectives on food banks as agents in population health. Community Dev. 2019, 50, 92-107. [CrossRef]

63. Loopstra, R.; Lambie-Mumford, H.; Fledderjohann, J. Food bank operational characteristics and rates of food bank use across Britain. BMC Public Health 2019, 19, 561. [CrossRef]

64. Mook, L.; Murdock, A.; Gundersen, C. Food banking and food insecurity in high-income countries. Voluntas 2020, 31, 833-840. [CrossRef]

65. Banca Pentru Alimente Bucuresti. Available online: http://bancapentrualimente.ro (accessed on 15 August 2020). 
66. Barker, M.; Russell, J. Feeding the food insecure in Britain: Learning from the 2020 COVID-19 crisis. Food Secur. 2020, 12, 865-870. [CrossRef]

67. Thompson, C.; Smith, D.; Cummins, S. Understanding the health and wellbeing challenges of the food banking system: A qualitative study of food bank users, providers and referrers in London. Soc. Sci. Med. 2018, 211, 95-101. [CrossRef]

68. Pulker, C.E.; Trapp, G.S.; Scott, J.A.; Pollard, C.M. Global supermarkets' corporate social responsibility commitments to public health: A content analysis. Glob. Health 2018, 14, 121. [CrossRef]

69. European Food Banks Federatioan (FEBA). Available online: https:/ / www.eurofoodbank.org (accessed on 15 August 2020). 